\title{
EVALUATION OF HEPATOPROTECTIVE EFFECT OF PROPOLIS AGAINST SUB-CHRONIC DIAZINON INDUCED HEPATOTOXICITY
}

\author{
Abeer Ramzy Hussieny Mahmoud and Nashwa Mohamad Mohamad Shalaby \\ Department of Forensic Medicine and Clinical Toxicology; Faculty of Medicine; Zagazig \\ University \\ Corresponding Author: Abeer Ramzy Hussieny Mahmoud \\ E-mail: lovelylomy_2009@yahoo.com Telephone: +201003436834
}

\begin{abstract}
Nowadays, the puplic health faces a major proplem of increased pesticides use with appearing of various side effects. One of the most commonly used is diazinon. It exerts its effects on variable tissues and cells including hepatocytes. This work aimed to study the tendency of diazinon to cause hepatic affection in rats and study the possible propolis protective role. We used 30 rats, divided into 4 groups; group Ia (-ve control); group Ib (+ve control, corn oil group); group II (propolis group; 400mg $/ \mathrm{kg} /$ day orally); group III (diazinon $20 \mathrm{mg} / \mathrm{kg} /$ day orally); group IV (diazinon $20 \mathrm{mg} / \mathrm{kg} /$ day + propolis $400 \mathrm{mg} / \mathrm{kg} /$ day orally) for 8 weeks. We studied biochemical parameters: serum aminotransferases (ALT and AST), tissue oxidative stress markers (hepatic MDA, hepatic catalase and hepatic GPx activities). Liver will be examined by light microscope to evaluate histopathological changes and immunohistochemical reaction to caspase 3 to predict apoptosis. Results indicated: Significant increase in the serum levels of the ALT and AST as well as hepatic MDA of diazinon treated rats compared to control group, whereas both hepatic catalase and GPx activities were significantly decreased these results had significantly improved in both propolis and diazinon group. Light microscopic examination revealed disruption in hepatic histoarchitecture in diazinon group unlike that in group III which returned near normal; while immunohistochemical staining showed many positive reacted cells to active caspase 3 in diazinon group which became few in group III near to control. In conclusion, this study demonstrated that diazinon may have hepatotoxic effects which can be protected by co-administration of propolis in adult rats. Further studies about diazinon effect on liver and about propolis role in hepatoprotection are recommended.

Key words: Diazinon, liver, oxidative stress, propolis.
\end{abstract}




\section{INTRODUCTION}

Environmental pollution regarding pesticide residues is a main concern as a result of their wide agricultural use. Organophosphorus insecticides (OPs) are one of the main classes of pesticides commonly used. Galloway and Handy, 2003 had revealed residuals of organophosphates in food stufs as fruits, vegetables, grains and others as well as water and soil.

Diazinon (DZN) is one of the excessevily utilized organophosphates agriculturally. Diazinon affects various organs ; such as liver, hematologic system, immune system, nervous system and kidney through cellular imbalance between over production of free radical and depleted tissue antioxidant mechanism (Galloway and Handy, 2003 and Yilmaz et al., 2012). Previous studies had reported that DZN might cause hepatotoxicity (Shadnia et al., 2007). One of the potential mechanisms of DZN induced hepatic affection was the overproduction of reactive oxygen species (ROS) (Teimouri et al., 2006).

Priyadarsini and Nagini, 2012 defined oxidative stress as imbalance between the compensatory reaction of endogenous anti-oxidants with increased production of reactive oxygen species.

Bee glue, Propolis, had been much familiar in the world for human health in traditional medicine and food supplementation (Pereira et al., 2008). It was believed that it could cure diabetes, heart diseases and even cancer. Several biological properties of propolis including antioxidant, antibiotic, anti-inflammatory and tumor cell arrest had also been reported (Moreno et al., 2000).
Kurek-G'orecka et al., 2014 and Tapas et al., 2008 explained that the principal antioxidant mechanism of propolis polyphenols can be summarized in the significant ability of "scavenger" reactive oxygen species and radical reactive nitrogen species so that reduction of xanthine oxidase reaction; chelate ion metals implicated in the sequence of free radical production, interrupt the reactions cascade of the lipids peroxidation and synergistic action added to different antioxidants.

So this work aimed to study the tendency of diazinon to cause hepatic affection in rats and study the possible propolis protective role

\section{MATERIAL\& METHODS \\ * Material}

[A] Chemicals

1. Diazinon:

DZN (99\% purity, CAS 333-41-5), soluble in petroleum or corn oil. It is colorless oil with very offensive odor. It was purchased from Sigma -aldrich Company.

2. Propolis: Propolis was produced by Sigma Pharmaceutical Industries (Cairo, Egypt) for International Business Establishment Co. (IBE pharma). It was existed in capsules of Biopropolis, each capsule contained $400 \mathrm{mg}$.

\section{[B] Animals:}

The study was done on 30 healthy adult male albino rats weighing 150$200 \mathrm{~g}$. Rats were got from the animal house of Zagazig Faculty of Medicine. We gave the rats balanced food consisting of milk, barley and bread, this food should be rich in all substances necessary to preserve their health before and during administration of the treatment. We gave them water 
in a different clean utunsiles. The experimental work was done according to the basic instructions advised through the Institutional Research Board for the use and care of experimental animals.

\section{[C]Experimental Design:}

Rats were randomly divided into four groups: Group I a (negative control group): No intervention was done to rats in this group for adjusting the basic parameters, and allowed drinking water ad libitum. Group I b (positive control group): Rats received $1 \mathrm{ml}$ corn oil orally for 8 weeks. Group II (Propolis group): Rats received propolis $(400 \mathrm{mg} / \mathrm{kg} /$ day) dissolved in corn oil orally for 8 weeks (Rahvar et al., 2018). Group III (diazinon treated group): The group was Orally received diazinon dissolved in corn oil. A daily dose of $20 \mathrm{mg} / \mathrm{kg}$ body weight which equals 1/20 of DZN LD50 (Gokcimen et al., 2007). Group IV (diazinon and Propolis): The group was administered diazinon $(20 \mathrm{mg} / \mathrm{kg}$ ) and $400 \mathrm{mg} / \mathrm{kg}$ Propolis orally once daily for 8 weeks.

\section{* Methods:}

Twenty- four hours after the end of experimental duration, the rats were subjected to sampling of blood and liver tissue as the follows:

- Collection of blood samples; Under light ether anesthesia, venous samples from the retro-orbital plexus were obtained by capillary glass tubes as described by Schemere (1967), to measure:

Alanine- aminotransferase (ALT) and Aspartate-aminotransferase (AST) Assay. The estimation was performed according to the method primarily introduced by Bergmeyer et al., 1978 and Saris, 1978.

- Tissue parameters:
Liver was immediately dissected out and grossly inspected to assess any gross abnormalities then washed with cold normal saline and used for:

* Estimation of catalase activity following the method of Luck (1974). and glutathione peroxidase activity in liver tissue following Paglia and Valentine (1967).

* Determination of the level of malondialdehyde in liver using the demonstrated method by Jain et al. (1989).

* Light microscope examination:

Fixation of the liver in $10 \%$ formalin saline then the tissues were firmed in blocks of paraffin and $5 \mu$ thickness sections were prepared then subjected for Hematoxylin and Eosin stains (Horobin and Bancroft, 1998) and then examined by light microscope. caspase 3:

* Immuno-histochmistry for

According to Ramos-Vara (2005) the site where antigen was present was clearly revealed by brown colouration in the cytoplasm. Collected results were tabulated and statistically analyzed using appropriate methods by Statistical Package of Social Science (SPSS), software version 22.0 (SPSS Inc., 2013). ANOVA with least significant differense Post hook test were used to find differense between the studied groups. Statistically significance was considered when $P$ value was $<0.05$ Histological studies were presented as photomicrographs and scientifically interpreted.

RESULTS
Biochemical results:
The results of this study had been
appropriately summarized, tabulated
and subjected to statistical analysis
before completion and graphic
illustration. ANOVA test was used in


this study to compare between means of different groups.

* As regard the groups; group Ia (ve control), group Ib (+ve control) \& group II (Propolis): There were a non significant differences $(\mathrm{p}>0.05)$ between groups all over the the study period using test of ANOVA (Table 1) as regard:
1- Serum ALT \& AST

2- Catalase \& GPx activity in hepatic tissues.

3- MDA in hepatic tissues.

So the negative control group was selected to be compared with the results of the treated groups; group III (diazinon ) and group IV (diazinon + Propolis).

Table 1: Statistical comparison among groups (Ia \& Ib \& II) as regard serum ALT\&AST, hepatic catalase, GPx activity and hepatic MDA along the period of the study by ANOVA test:

\begin{tabular}{|c|c|c|c|c|c|}
\hline Group & $\begin{array}{c}\text {-ve control } \\
\text { group(Ia) } \\
\text { Mean } \pm \text { SD }\end{array}$ & $\begin{array}{c}\text { +ve control } \\
\text { group(Ib) } \\
\text { Mean } \pm \text { SD }\end{array}$ & $\begin{array}{c}\text { Propolis } \\
\text { group (II) } \\
\text { Mean } \pm \text { SD }\end{array}$ & F & P \\
\hline Serum AST (mg/dl) & $14.13 \pm 3.49$ & $14.15 \pm 3.28$ & $13.9 \pm 2.88$ & 0.011 & $>0.05$ \\
\hline Serum ALT (mg/dl) & $25.3 \pm 3.40$ & $24.9 \pm 3.14$ & $24.1 \pm 3.01$ & 0.220 & $>0.05$ \\
\hline Gpx (U/g protein) & $28 \pm 4.62$ & $27.84 \pm 4.53$ & $28.36 \pm 5.43$ & 0.018 & $>0.05$ \\
\hline Catalase (U/g protein) & $66.31 \pm 4.35$ & $67.01 \pm 3.98$ & $68.44 \pm 8.28$ & 0.205 & $>0.05$ \\
\hline $\begin{array}{c}\text { MDA (n mol/mg } \\
\text { protein) }\end{array}$ & $98.35 \pm 8.99$ & $99.07 \pm 9.4$ & $99.95 \pm 10.33$ & 0.042 & $>0.05$ \\
\hline
\end{tabular}

N.B: Number of rats $=6$ rats for each group. $S D=$ Standard Deviation. $p>0.05=$ non significant

* As regard the treated groups; group III (diazinon) \& group IV (diazinon + Propolis):

The result of this study showed significant differense between these groups in all parameters when compared with -ve control group. Using LSD it was found that there was significant increase of serum ALT \& AST levels and MDA in hepatic tissue with significant decrease of catalase and GPx activity in hepatic tissue in group III (diazinon) when compared with group Ia (-ve control). Also these differnses was found between group III (diazinon ) and group IV (diazinon + Propolis).No differense was found between group I (control) and group IV (diazinon + Propolis).So intake of Propolis with diazinon can significantly prevent these changes (table 2). 
Table (2): Statistical comparison among the negative control (Ia), diazinon (III) and diazinon and propolis (IV) groups as regard ALT \& AST, hepatic GPx, and catalase enzymatic activity and MDA levels in hepatic tissues by ANOVA test.

\begin{tabular}{|c|c|c|c|c|c|}
\hline $\begin{array}{c}\text { Group } \\
\text { Parameter }\end{array}$ & $\begin{array}{c}\text {-ve control } \\
\text { (group Ia) } \\
\text { Mean } \pm \text { SD }\end{array}$ & $\begin{array}{c}\text { Diazinon } \\
\text { (Group III) } \\
\text { Mean } \pm \text { SD }\end{array}$ & $\begin{array}{c}\text { Diazinon+Propol } \\
\text { is (Group IV) } \\
\text { Mean } \pm \text { SD }\end{array}$ & F & P \\
\hline $\begin{array}{c}\text { Serum AST } \\
(\mathrm{mg} / \mathrm{dl})\end{array}$ & $14.13 \pm 3.49^{\mathrm{a}}$ & $95.29 \pm 3.47^{\mathrm{b}}$ & $15 \pm 4.13^{\mathrm{a}}$ & 947.300 & $<0.001^{* *}$ \\
\hline $\begin{array}{c}\text { Serum ALT } \\
(\mathrm{mg} / \mathrm{dl})\end{array}$ & $25.3 \pm 3.40^{\mathrm{a}}$ & $\begin{array}{c}105.77 \pm 17 . \\
44^{\mathrm{b}}\end{array}$ & $24.8 \pm 4.71^{\mathrm{a}}$ & 115.702 & $<0.001^{* *}$ \\
\hline $\begin{array}{c}\text { GPx (U/g } \\
\text { protein) }\end{array}$ & $28 \pm 4.62^{\mathrm{a}}$ & $10.62 \pm 1.6^{\mathrm{b}}$ & $29.14 \pm 5.77^{\mathrm{a}}$ & 33.901 & $<0.001^{* *}$ \\
\hline $\begin{array}{c}\text { Catalase (U/g } \\
\text { protein) }\end{array}$ & $66.31 \pm 4.35^{\mathrm{a}}$ & $\begin{array}{c}26.70 \pm 4.48 \\
\mathrm{~b}^{\mathrm{a}}\end{array}$ & $64 \pm 6.72^{\mathrm{a}}$ & 105.723 & $<0.001^{* *}$ \\
\hline $\begin{array}{c}\text { MDA } \\
(\text { nmol/mg } \\
\text { protein) }\end{array}$ & $98.35 \pm 8.99^{\mathrm{a}}$ & $\begin{array}{c}402.34 \pm 4.9 \\
7^{\mathrm{b}}\end{array}$ & $93.38 \pm 5.18^{\mathrm{a}}$ & $4,258.846$ & $<0.001^{* *}$ \\
\hline
\end{tabular}

N: Number of sacrificed rats for every group was 6 rats. SD : Standard Deviation. **: Highly-significant (P<0.01). LSD:Groups with different letters are statistically highly different $(\mathbf{P}<0.01)$.

\section{II)-Histopathological changes:}

Light microscopic examination of sections from the liver of groups I \& II showed the same structures. They showed normal architecture of classic hepatic lobule with arranged bands of hepatocytes ramifing from the central vein to the periphery of the lobules which contain the portal tracts. The periportal and pericentral hepatocytes were polyhedral containing central vesicular nucleus surrounded with acidophilic cytoplasm. They were separated by narrow blood sinusoids (fig., 1).

While the liver of rats treated with diazinon showed venous congestion, many hepatocytes with vacuolated cytoplasm and deeply stained shrunken nuclei, dilated sinusoids and areas of cellular infilterates (fig. 2), these changes are less in group IV (fig., 3).

Immunohistochemical staining for caspase 3 of liver in groups I \& II showed little positive reaction (brown color) of few hepatocytes for activated caspase 3 (fig., 4 ).

In diazinon treated group, there was extensive positive reaction to caspase 3 (fig., 5). Which became less in group IV (fig., 6). 


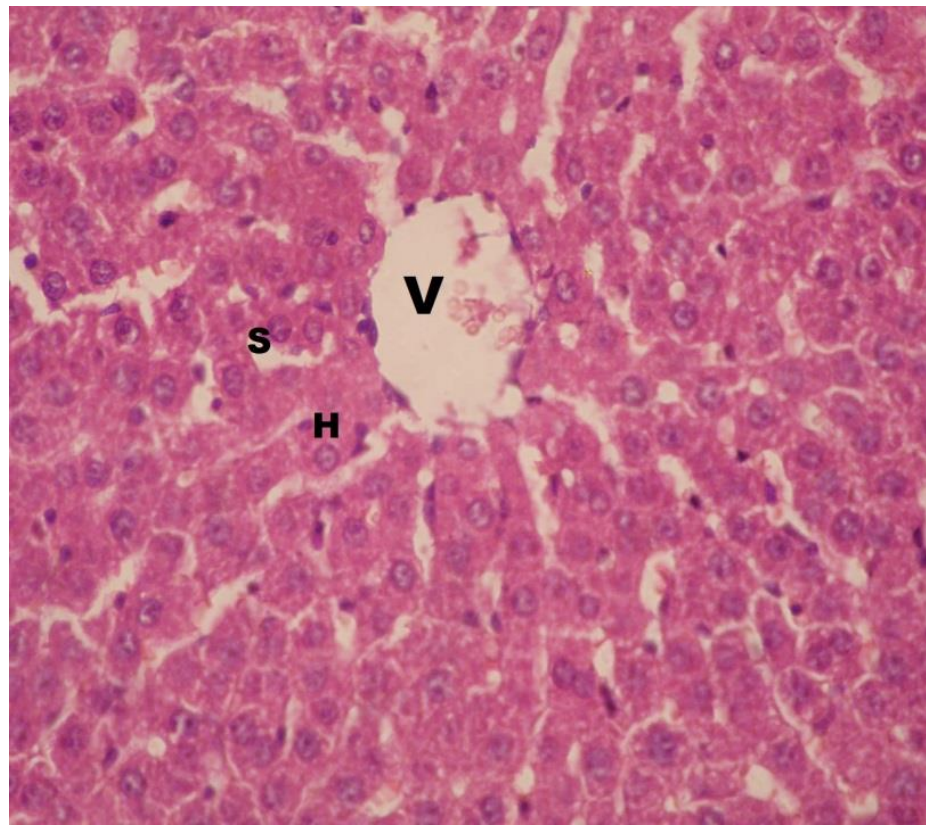

Figure (1): A photomicrograph of a section from the liver of a control group showing hepatocytes $(\mathrm{H})$ arranged in plates radiating from the central vein $(\mathrm{V})$ and separated by blood sinusoids $(\mathrm{S})$; hepatocytes are polygonal in shape, with central rounded vesicular nuclei and acidophilic cytoplasm. (H\&E X 400)

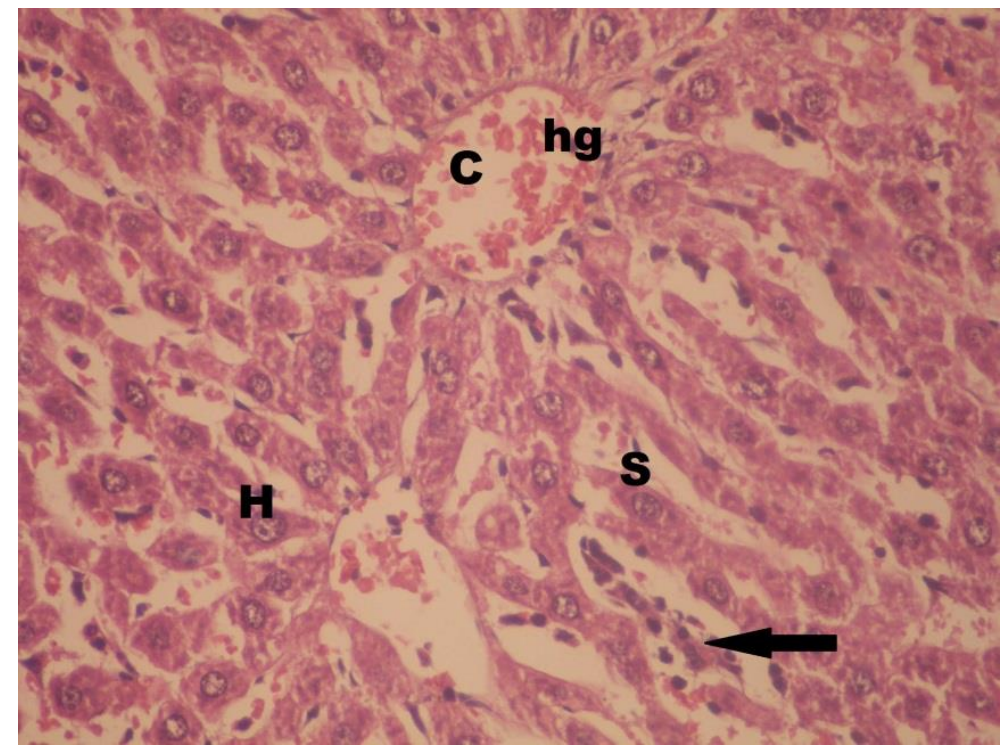

Figure (2): A photomicrograph of a section of liver of diazinon treated group showing congested (hg) central vein (C), dilated sinusoids (S), deeply stained shrunken nuclei of hepatocytes $(\mathrm{H})$ and cellular infltrations (arrow). (H\&E X 400) 


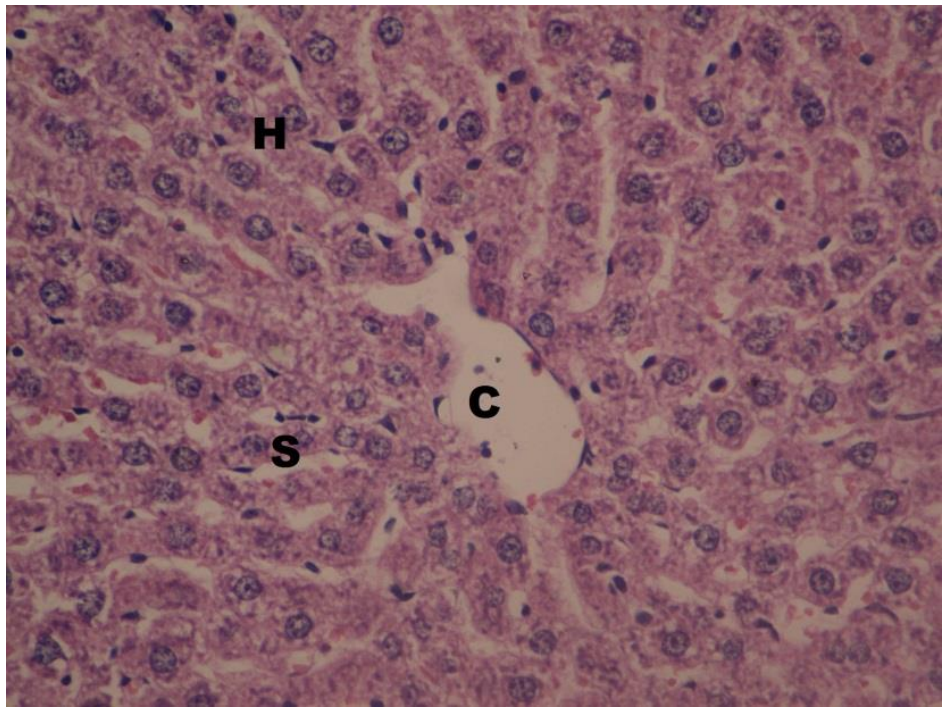

Figure (3): A photomicrograph of a section of liver of group IV (diazinon and propolis) treated group showing central vein $(\mathrm{C})$, less dilated sinusoids $(\mathrm{S})$ and hepatocytes (H) (H\&E X 400).

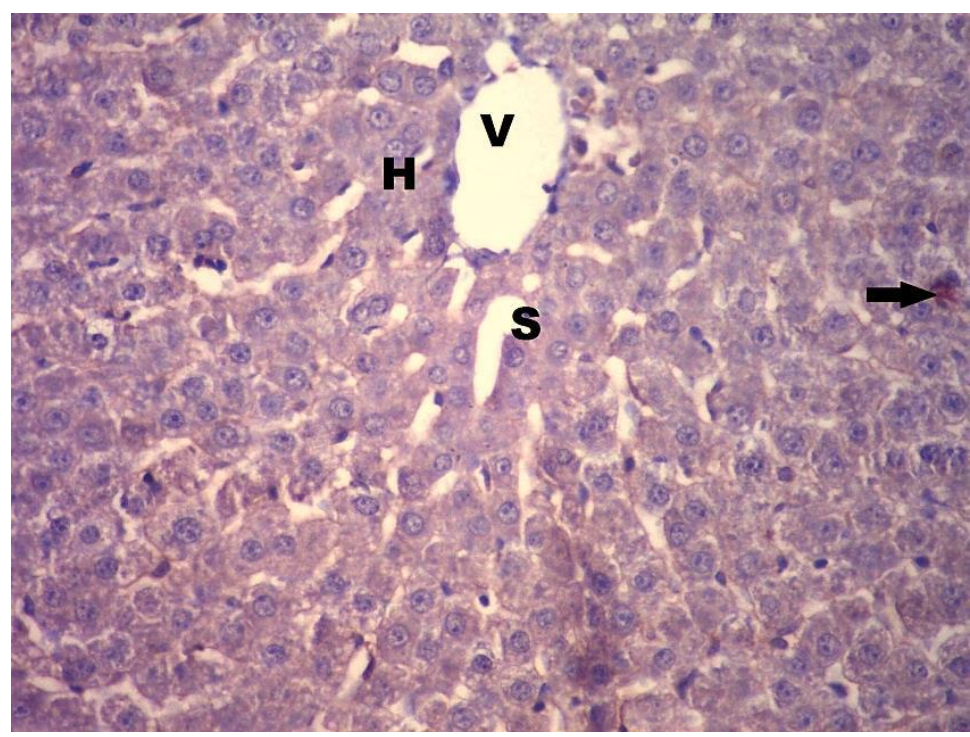

Figure (4): photomicrograph of a section from the liver of a control group showing few positive reaction for activated caspase 3 in few hepatocytes (arrow) (Caspase 3 immunostaining X 400). 


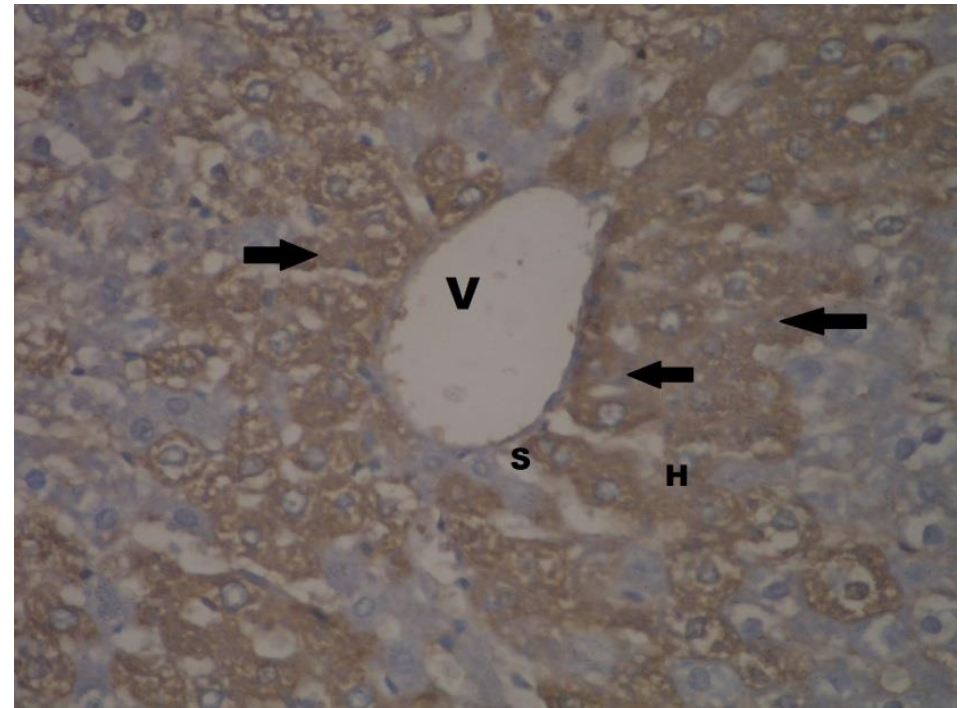

Figure (5): A photomicrograph of liver from diazinon treated group showing many positive reacted cells for activated caspase 3 (arrows) in cytoplasm of hepatocytes (H) (Caspase 3 immunostaining X 400).

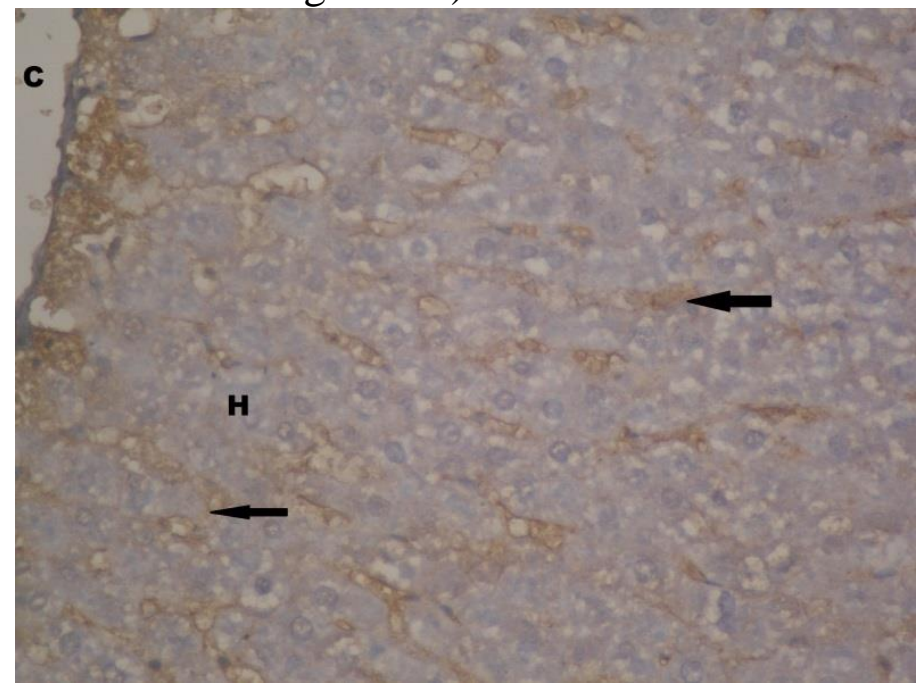

Figure (6): photomicrograph of a section from the liver of diazinon and propolis group showing less positive reaction for activated caspase 3 in few hepatocytes (arrows) (Caspase 3 immunostaining X 400).

\section{DISCUSSION}

Agricultural extensive use of pesticides and its resulting residuals is considered a universal bother. One of the main classes of pesticides used is organophosphorus compounds which were detected in food, soil and drinking water as residuals (Costa, 2006).

Diazinon is considerd one of the globally used organophosphates. Impact of low levels chronic exposure to DZN on human health was reported in only few studies. Hepatotoxicity had been reported to be induced by DZN. It was reported that DZN could elevate liver transaminases;AST\& ALT and alkaline phosphatase. Also; it was studied that DZN could induce dosedependent liver affection both biochemically and histopathologically (Azmi et al., 2006; Gokcimen et al., 2007 and Kalender et al., 2005).

In the current study, a high significant elevation in AST and ALT mean values in DZN administered group was detected as opposite to their 
corresponding ones in control group. A significant decrease in these enzymes mean values was observed after administration of propolis with DZN when compared with the corresponding results in DZN administered group.

Alfahdawi, 2011 considered that aminotransferases are most useful in hepatocellular disease diagnosis and monitoring.

Srivastava and Raizada, 1999 explained that the increase in these enzyme activities reflected active liver destruction. While Gaskill et al. (2005) declared that, ALT release from the cytoplasm of hepatic cells could have occurred secondary to cellular necrosis.

In agreement with these results Sarhan and Al-Sahhaf (2011) reported that, AST and ALT showed a significant increase in serum of rabbits that received diazinon $20 \mathrm{mg} / \mathrm{kg}$ for 4 weeks.

In the existing study, we estimated hepatotoxicity resulting from chronic DZN exposure in rat and its possible mechanism as lipid peroxidation and apoptosis and the potential effect of propolis in its protection.

The present study also showed a significant rise in hepatic MDA in DZN treated group when correlated with control group while a significant decrease in its mean value was observed after administration of propolis with DZN when compared with the corresponding results in DZN administered group.

Also, the present study reported a significant decrease in hepatic GPx and catalase activities with significant increase in MDA in DZN treated group when compared with control group. Administration of propolis with DZN caused a significant improvement in these mean values as compared to their corresponding values in DZN administered group.

These results were matched with Caughlan et al., 2004; Kaur et al., 2007; Li, 2007; Oral et al., 2006; Rush et al., 2010 and Tenn and Wang, 2007 who supposed that the elevation of reactive oxygen species level was the core mechanism of chronic organophosphates toxicity.

MDA was deemed to be one of the indicators of oxidative stress occurance or lipid peroxidation (Nair et al., 2008). Many researchs had reported peroxidative effects and lipid peroxidation of different organophosphate compounds (Bhatti et al., 2010; El-Shenawy, 2010; Ghafour-Rashidi et al., 2007 and Spodniewska and Zasadowski, 2008).

El-Shenawy et al., 2010 studied that coadministration of vitamin $E$ had alleviated the oxidative stress of DZN after 14 days diazinon exposure of 32.5 $\mathrm{mg} / \mathrm{kg}$ that caused elevated oxidative stress biomarkers and dimnished the antioxidant defenses like catalase, glutathione and superoxide dismutase activities.

Also; Mehta et al., 2009 studied that the organophosphate insecticide; chlorpyrifos created abnormal changes in the rat liver levels of nitrate, hydrogen peroxide, and nitrite.

In agreement with the previous; Jasprica et al. (2007) and Newairy et al., (2009) explained that propolis caused significant decrease in TBARS levels which are indicators of lipid peroxidation and increase in CAT, GPx, and SOD activities.

On the other hand, the above mentioned biochemical results obtained in the present study had been supported by findings in light microscopic 
histopathologic examination and immunohistochemical staining of liver sections.

The histological results showed that DZN induced several histopathological alterations in the liver. Many hepatic lobules showed dilatation of the sinusoidal spaces, inflammatory cellular infiltration, congested veins, shrunken hepatocytes with darkly stained nuclei.

These findings were in agree with Sarhan and Al-Sahhaf (2011) who reported leucocytic infiltrations, congestion of veins, cytoplasmic vacuolation of the hepatocytes and fatty degeneration in liver samples of rats received DZN.

In the present work, adding propolis with DZN to rats showed improvement in the form of preserved normal hepatic lobular architecture and uncongested veins. Less dilated sinusoidal spaces and few cellular infiltration were observed.

Also, we studied the activated form of caspases-3. Our study showed that DZN induced apoptosis in hepatocytes of the rats treated with DZN through activation of caspases -3 .

Caspases are deemed to be the key moderator of apoptosis. Caspase-3 is known to be the a final main implementer of apoptosis. It is responsible for the splitting of the key cellular proteins, leading to the known morphological modulations observed in apoptotic cells (Budihardjo et al., 1999 and Fischer et al., 2003).

Many studies had shown the apoptotic effects of variable organophosphate compounds like Caughlan et al. (2004) who determinded that the chlorphyrifos organophosphorus compound had induced apoptosis in rat cortical neurons.

Kaur et al. (2007) showed that long term exposure to the organophosphorus compound; dichlorvos even in low levels resulted in neuronal apoptosis with mitochondrial functional impairement.

Furthermore, the activation of caspase-3 was alleviated in DZN and propolis group significantly to a near level of control group.

Antecedent studies had demonsterated the action of propolis as anti-apoptosis. This is because its high content of flavonoids that had been shown to be able to scavenge free radicals and so protect the cell membrane from lipid peroxidation (Pinchuk and Lichtenberg, 2002).

According to El-Masry et al., 2011 propolis contains twelve different flavonoids including rutin, luteolin, naringenin, quercetin and others; in addition to phenolic acids, caffeic and cinnamic acid. In addition to that, Haro et al., 2002 reported that propolis was considered an eminent provenance of substantial trace elements, like iron, magnesium,copper and others which might provide optimum trace elements responsible for antioxidant enzymes reactivation.

Kanbura et al., 2009 assumed that the first mechanism of propolis effect might need the free radicals scavenging that motivate lipid peroxidation. The second mechanism might inhibit xanthine oxidase, which is known to cause generation of free radicals.

Added to the above, Nirala et al., 2008 reported that propolis was fit to protect the liver against paracetamol hepatotoxicity in mice and Omar et al. (2016) also found that propolis had induced a reduction in the elevated 
serum ALT and AST activity in doxorubicin treated rats.

On the other hand, Yousef et al., (2003a\& b) explained that administraton of constituent of propolis; isoflavones had minimized cypermethrin toxicities and this might be due to the isoflavone antioxidant properities. Moreover, the results of Yousef et al., $(2004 a \&$ b) studied that isoflavone doses of 2.5 or $5 \mathrm{mg} / \mathrm{kg}$, had beneficial effect on plasma lipid and lipoprotein concentrations, and antioxidant activities in rabbits.

The results of the current study also go parallel with Eraslan et al., (2008) who reported the antioxidant protective action of propolis against cypermethrin treated rats.

\section{CONCLUSION}

Taking the previous findings together, it can be concluded that hepatic apoptosis through oxidative stress pathway can be induced by sub-chronic DZN exposure which can be alleviated by propolis coadministration.

\section{RECOMMENDATIONS}

Further studies about diazinon effect on liver and about propolis role in hepatoprotection are recommended.

\section{REFERENCES}

Alfahdawi, H.Y. (2011): Estimation of some haematological parameters and enzymes activity transaminase for some arthritis patients who used voltaren drug in AL-Ramadi city. Tikrit Journal of Pure Science; 16 (4):28-30.

Azmi, M.A.; Naqvi, S.N.H. and Aslam, M. (2006): Effect of pesticide residues on health and different enzyme levels in the blood of farm workers from Gadap (rural area)

Karachi-Pakistan.

Chemosphere 64(10): 1739-1744.

Bergmeyer, H.V.; Scheibe, P. and Wahlefeld, A.W.

(1978):

Optimization methods for aspartate aminotransferase and alanine aminotransferase. Clin. Chem., 24(1):58-73.

Bhatti, G.; Kiran, R. and Sandhir, R. (2010) Modulation of ethioninduced hepatotoxicity and oxidative stress by vitamin E supplementation in male Wistar rats. Pesticide Biochemistry and Physiology; 98(1): 26-32.

Budihardjo, I.; Oliver, H.; Lutter, M.; Luo, X. and Wang, X. (1999): Biochemical pathways of caspase activation during apoptosis. Annu. Rev. Cell Dev. Biol., 15: 269 2

$$
9
$$$$
0
$$

Caughlan, A.; Newhouse, K.; Namgung, U. and Xia, Z. (2004): Chlorphyrifos induces apoptosis in rat cortical neurons that is regulated by a balance between p38 and ERK/ JNK MAP kinases. Toxicological Sciences; 78(1): 125-134.

Caughlan, A.; Newhouse, K.; Namgung, U. and Xia, Z. (2004): Chlorphyrifos induces apoptosis in rat cortical neurons that is regulated by a balance between p38 and ERK/ JNK MAP kinases. Toxicological Sciences; 78(1): 125-134.

Costa, L.G. (2006): Current issues in organophosphate toxicology. Clinica. Chimica. Acta.; 366(1): 113.

El-Masry, T.A.; Emara, A.M. and ElShitany, N.A. (2011): Possible protective effect of propolis against lead induced neurotoxicity in 
animal model. J. Evol. Biol. Res.; 3 (1): 4-11.

El-Shenawy, N.S.; El-Salmy, F.; AlEisa, R.A. and El- Ahmary, B. (2010): Amelioratory effect of vitamin $\mathrm{E}$ on organophosphorus insecticide diazinon-induced oxidative stress in mice liver. Pesticide Biochem. Physiol., 96 :101-107.

Eraslan, G.; Kanbur, M.; Silici, S.; Altinordulu, S. and Karabacak, M. (2008): Effects of cypermethrin on some biochemical changes in rats: the protective role of propolis, Exp. Anim.; 57: 453-460.

Fischer, U.; Janicke, R.U and Schulze-Osthoff, K. (2003): Many cuts to ruin: A comprehensive update of caspase substrates. Cell Death Differ.; 10(1):76-100.

Galloway, T. and Handy, R. (2003): Immunotoxicity of organophosphorous pesticides. Ecotoxicology; 12(1-4): 345-363.

Gaskill, C.L.; Miller, L.M.; Mattoon, J.S.; Hoffmann, W.E.; Burton, S.A. and Gelens, H.C. (2005): Liver histopathology and liver and serum alanine aminotransferase and alkaline phosphatase activities in epileptic dogs receiving phenobarbital. Vet. Pathol., 42:147$1 \quad 6 \quad 0$

Ghafour-Rashidi, Z.; DermenakiFarahani, E.; Aliahmadi, A.; Esmaily, H.; Mohammadirad, A.; Ostad, S. N. and Abdollahi, M. (2007): Protection by cAMP and cGMP phosphodiesterase inhibitors of diazinon-induced hyperglycemia and oxidative/nitrosative stress in rat Langerhans islets cells: molecular evidence for involvement of noncholinergic mechanisms. Pesticide
Biochemistry and Physiology; 87(3): 261-270.

Gokcimen, A.; Gulle, K.; Demirin, H.; Bayram, D.; Kocak, A. and Altuntas, I. (2007): Effects of diazinon at different doses on rat liver and pancreas tissues. Pestic. Biochem. Physiol., 87 :103-108.

Gokcimen, A.; Gulle, K.; Demirin, H.; Bayram, D.; Kocak, A. and Altuntas, I. (2007): Effects of diazinon at different doses on rat liver and pancreas tissues. Pesticide Biochemistry and Physiology 87(2): 103-108.

Haro, A.; Lopez-Aliaga, I.; Lisbona, F.; Barrionuevo, M.; Alferez, M.J.M. and Campos, M.S. (2002): Beneficial effect of pollen and/or propolis on the metabolism of iron, calcium, phosphorus, and magnesium in rats with nutritional ferropenic anemia. J. Agric. Food Chem. 48, 5715-5722.

Horobin, R.W. and Bancroft, J.D. (1998): Hematoxylin and eosin as an oversight stain. In: Trubleshooting Histology stains, $1^{\text {st }}$ ed., Churchill Livingstone Press, San Francisco, pp. 88- 93.

Horobin, R.W. and Bancroft, J.D. (1998): Hematoxylin and eosin as an oversight stain. In: Troubleshooting Histology stains, $1^{\text {st }}$ ed., Churchill Livingstone Press, San Francisco, pp. 88- 93.

Jain, S.K.; McVie, R.; Duett, J.; and Herbst, J.J. (1989): Erythrocyte membrane lipid peroxidation and glycolylated hemoglobin in diabetes. Diabetes, 38: 1539-1543.

Jasprica, D.; Mornar, A.; Debelijak, Z.; Smolcic-Bubalo A.; MedicSaric, M.; Mayer, L.; Romic, Z.; Bucan, K.; Balog, T., Sobocanec, S. and Sverko, V., (2007): In vivo 
study of propolis supplementation effects on antioxidative status and red blood cells. Journal of Ethnopharmacol; 110(3): 548-554.

Kalender, S.; Ogutcu, A.; Uzunhisarcikli, M.; Açikgoz, F., Durak, D., Ulusoy, Y. and Kalender, Y. (2005): Diazinon-induced hepatotoxicity and protective effect of vitamin $E$ on some biochemical indices and ultrastructural changes. Toxicology 211(3): 197-206.

Kanbura, M.; Eraslan, G. and Silici, S. (2009): Antioxidant effect of propolis against exposure to propetamphos in rats. Ecotoxicol. Environ. Safety 72, 909-915.

Kaur, P.; Radotra, B.; Minz, R.W. and Gill, K. D. (2007): Impaired mitochondrial energy metabolism and neuronal apoptotic cell death after chronic dichlorvos (OP) exposure in rat brain. Neurotoxicology 28(6): $1208-$ 1219.

Kurek-G'orecka, A. ; RzepeckaStojko, A. ; G'orecki, M. ; Stojko, J. Sosada, M. and SwierczekZieba, G. (2014): Structure and antioxidant activity of polyphenols derived from propolis. Molecules; 19 (1): 78-101.

Li, Q. (2007): New mechanism of organophosphorous pesticideinduced immunotoxicity. Journal of Nippon Medical School 74(2): 92105.

Luck, H. (1974): Catalase. In methods of enzymatic analysis. (Ed.Begmeyer HU) Academic press, New York: 885 -890.

Mehta, A.; Verma, R. S. and Srivastava, N. (2009): Chlorpyrifos induced alterations in the levels of hydrogen peroxide, nitrate and nitrite in rat brain and liver. Pesticide Biochemistry and Physiology; 94(2-3): 55-59.

Moreno, M.; Isla, M.; Sampetro, A. and Vattunoe, M. (2000): Comparison of the free radical scavenging activity of propolis from several region of Argentina. Journal of Ethnopharmacol; 71(12): 109-114.

Nair, V.; O'Neil, C. and Wang, P. (2008): Malondialdehyde. Encyclopedia of Reagents for Organic Synthesis. New York, N.Y.: John Wiley \& Sons.

Newairy, A. A. ;Salama, A. F.; Hussien, H. M. and Yousef, M. I. (2009): Propolis alleviates aluminum-induced lipid peroxidation and biochemical parameters in male rats. Food and Chemical Toxicology; 47: 10931098.

Nirala, S. K.; Bhadauria, M.; Shukla, S.; Agrawal, O. P.; Mathur, A.; Li, P. Q. and Mathur, R. (2008) : Pharmacological intervention of tiferron and propolis to alleviate beryllium-induced hepatorenal toxicity. Fundam. Clin. Pharmacol; 22(4): 403-415.

Omar, N.A.A.; Allithy, A.N.A.; Baghdadi, H.; Zolaly, M.; Abdelhaleem, M.; Helmy, M. M.; Ayat, M.M.A. and El-Sayed, S.M. (2016): Hepatoprotective effects exerted by propolis against doxorubicin-induced rat liver toxicity: a biochemical and histopathological study. Am. J. Cancer Prevention; 4 (3), 36-40.

Oral, B.; Guney, M.; Demirin, H.; Ozguner, M. ; Giray, S. G. ; Take, G. ;Mungan, T. and Altuntas, I .(2006): Endometrial damage and apoptosis 
in rats induced by dichlorvos and ameliorating effect of antioxidant vitamins $\mathrm{E}$ and $\mathrm{C}$. Reproductive Toxicology 22(4): 783-790.

Paglia, D.E. and Valentine W.N. (1967): studies on the quantitative and qualitative characterization of erythrocytes glutathione peroxidase . J. Lab. Clin. Med., 70: 58- 169.

Pereira, A. D.; Andrade, S. F.; Oliveira, M. S. and Maistre, E. L. (2008): First in vivo evaluation of the mutagenic effect of Brazilian green propolis by comet assay and micronucleus test. Food and Chemical Toxicology; 46(7): 25802584.

Pinchuk, I. and Lichtenberg, D. (2002): The mechanism of action of antioxidants against lipoprotein peroxidation, evaluation based on kinetic experiments. Progress in Lipid Research; 41(4): 279-314.

Priyadarsini, R.V. and Nagini, S. (2012): Quercetin suppresses cytochrome $\mathrm{P} 450$ mediated ROS generation and NF kappaB activation to inhibit the development of 7,12-dimethylbenz a anthracene (DMBA) induced hamster buccal pouch carcinomas. Free Radic. Res.; 46: 41-49.

Rahvar, M.; Owji, A. A. and Mashayekhi, F. J. (2018): Effect of quercetin on the brain-derived neurotrophic factor gene expression in the rat brain. Bratisl. Med. J. ; 119 (1): 28-31.

Ramos-Vara, J.A. (2005): "Technical aspects of immunohistochemistry". Vet. Pathol., 42: 409.

Rush, T.; Liu, X. Q.; Hjelmhaug, J. and Lobner D. (2010) Mechanisms of chlorpyrifos and diazinon induced neurotoxicity in cortical culture. Neuroscience 166(3): 899-906.

Sarhan, O.M.M. and Al-Sahhaf, Z.Y. (2011): Histological and Biochemical Effects of Diazinon on Liver and Kidney of Rabbits. Life Science Journal, 8 (4):1183-1189.

Saris, N.E. (1978): Revised IFCC method for aspartame aminotransferase. Clin. Chem., 24(1): 720-721.

Schemere, S. (1967): The blood morphology of laboratory animals, $3^{\text {rd }}$ ed., C.V. Mosby Co, P.P. 1065.

Shadnia, S.; Dasgar, M.; Taghikhani, S.; Mohammadirad, A.; Khorasani, R. and Abdollahi, $M$. (2007): Protective Effects of alphaTocopherol and N-Acetyl-Cysteine on Diazinon-Induced Oxidative Stress and Acetylcholinesterase Inhibition in Rats. Toxicol. Mech. Methods.; 17(2):109-15.

Spodniewska, A. and Zasadowski, A. (2008): Content of glutathione and vitamin $C$ in the liver of rats exposed to dimethoate and pyrantel tartrate. Acta. Veterinaria. Brno. $77(3): 355-362$.

SPSS Inc (2013): SPSS for windows, version 22.0. Chicago, SPSS Inc. http://www.unimunester.de/imperia /md/content/ziv/service/software. e/spss/handbuecher/englisch/spss_b rief guide_22.0.pdf.

Srivastava, M.K. and Raizada, R.B. (1999) : Assessment of the noobserved-effect level (NOEL) of quinalphos in pregnant rats. Food Chem. Toxicol., 37: 649-653.

Tapas, A. R. ; Sakarkar, D. M. and Kakde, R. B. (2008): Flavonoids as nutraceuticals: a review. Tropical Journal of Pharmaceutical Research; 7 (3): 1089-1099. 
Teimouri, F.; Amirkabirian, N.; Esmaily, H.; Mohammadirad, A.; Aliahmadi, A. and Abdollahi, M. (2006): Alteration of hepatic cells glucose metabolism as a noncholinergic detoxication mechanism in counteracting diazinon-induced oxidative stress. Hum. Exp. Toxicol.; 25(12):697703.

Tenn, C.C. and Wang, Y. (2007): VXinduced cell death involves activation of caspase- 3 in cultured rat cortical neurons. Neuroscience Letters 417(2): 155-159.

Yilmaz, N.; Yilmaz, M. and Altuntas, I. (2012): Diazinon-induced brain toxicity and protection by vitamins $\mathrm{E}$ plus C. Toxicol. Ind. Health;28(1):51-7.

Yousef, M.I.; El-Demerdash, F.M. and Al-Salhen, K.S. (2003)a: Protective role of isoflavones against the toxic effect of cypermethrin on semen quality and testosterone levels of rabbits. J. Environ. Sci. Health; 38: 463-478.

Yousef, M.I.; El-Demerdash, F.M.; Kamel, K.I. and Al-Salhen, K.S., (2003)b: Changes in some haematological and biochemical indices of rabbits induced by isoflavones and cypermethrin. Toxicology; 189: 223-234.

Yousef, M.I.; Esmail, A.M. and Baghdadi, H.H. (2004) a: Effect of isoflavones on reproductive performance, testosterone levels, lipid per oxidation and seminal plasma biochemistry of male rabbits. J. Environ. Sci. Health; 39: 819-833.

Yousef, M.I.; Kamel, I.K.; Esmail, A.M. and Baghdadi, H.H. (2004) b: Antioxidant activities and lipid lowering effects of isoflavone in male rabbits. Food Chem. Toxicol; 42: 1497-1503. 


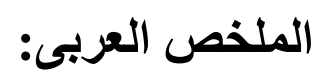 \\ تقييم الدور الوقائى لصمغ العل ضد التسمم الكبدى الناتج من التعرض التربن دون المزمن لمادة الديازينون}

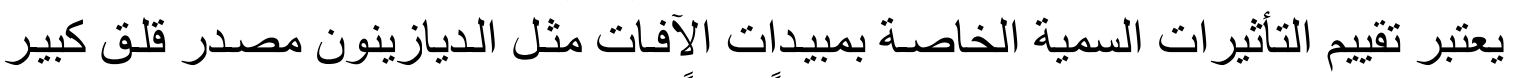

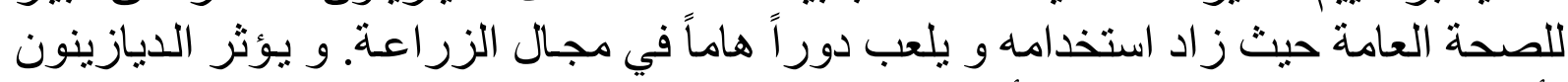

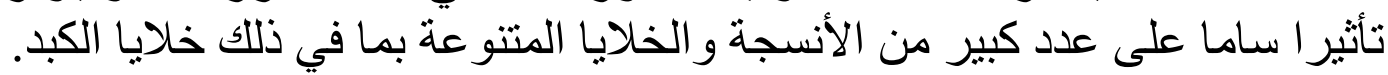

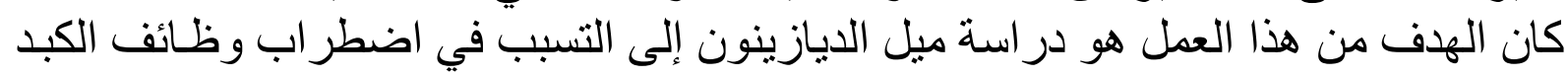

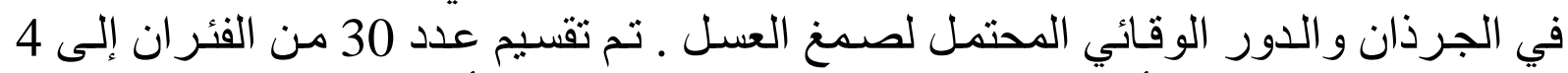

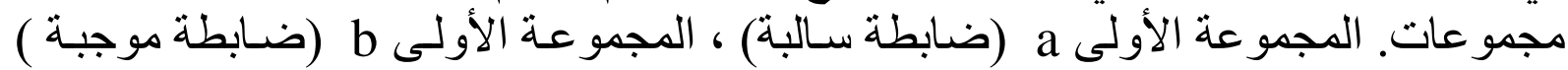

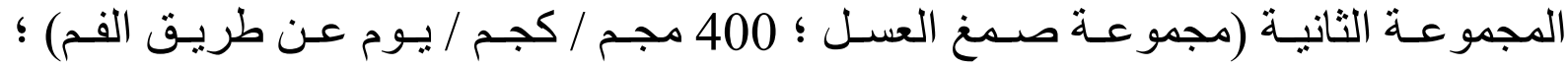

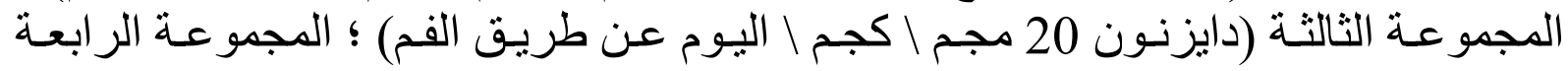

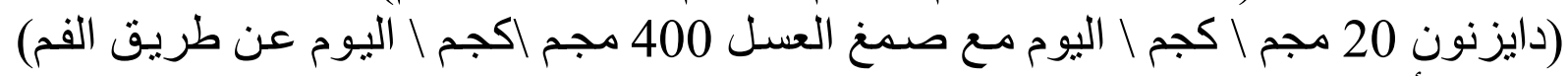

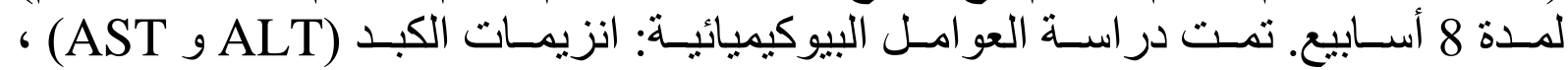

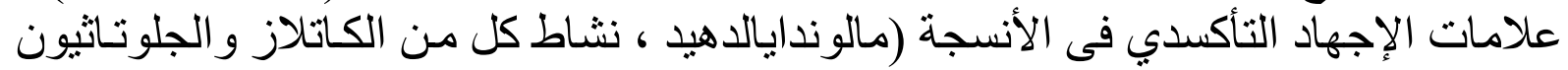

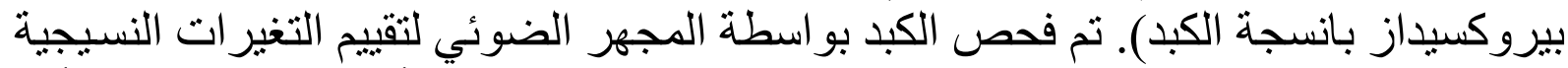

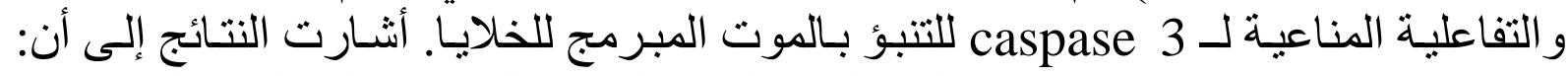

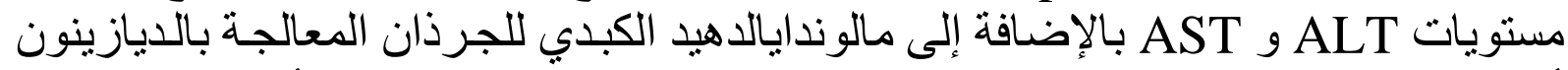

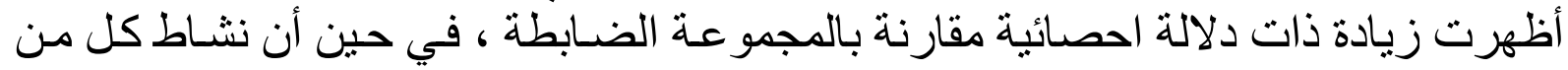

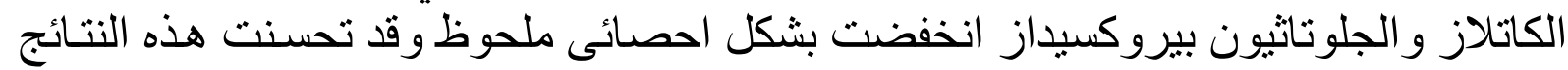

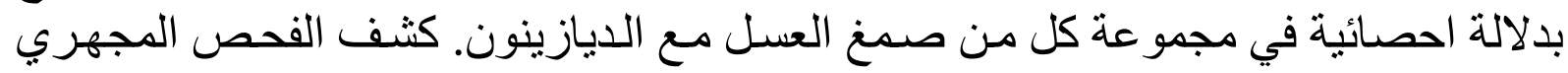

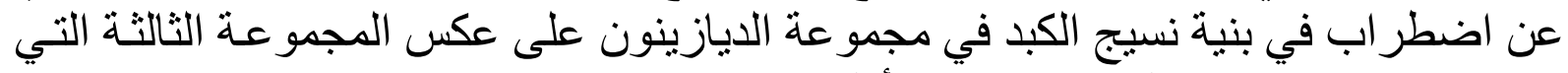

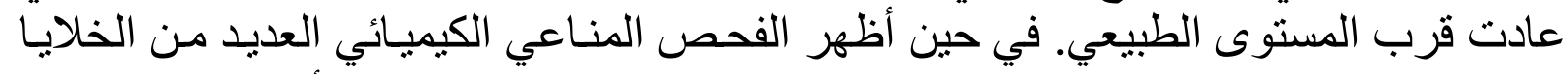

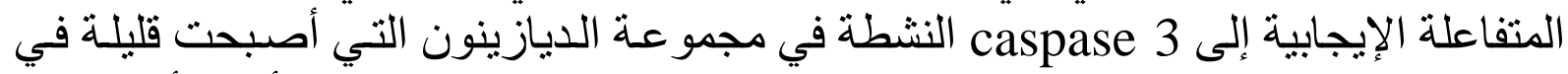

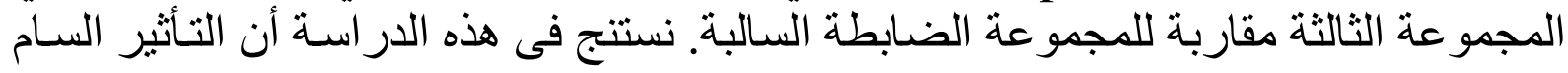

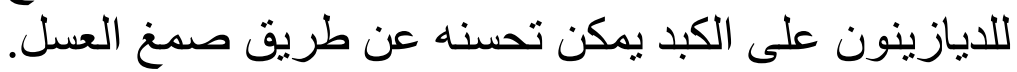

